\title{
Assessing the transport of pharmaceutical compounds in a layered aquifer discharging to a stream
}

Balbarini, Nicola; Frederiksen, Majken; Rønde, Vinni Kampman; Møller, Ingelise; Sonne, Anne Thobo; McKnight, Ursula S.; Pedersen, Jørn Kristian; Binning, Philip John; Bjerg, Poul Løgstrup

\section{Published in:}

Ground Water

Link to article, DOI:

10.1111/gwat.12904

Publication date:

2020

Document Version

Peer reviewed version

Link back to DTU Orbit

Citation (APA):

Balbarini, N., Frederiksen, M., Rønde, V. K., Møller, I., Sonne, A. T., McKnight, U. S., Pedersen, J. K., Binning, P. J., \& Bjerg, P. L. (2020). Assessing the transport of pharmaceutical compounds in a layered aquifer discharging to a stream. Ground Water, 58(2), 208-223. https://doi.org/10.1111/gwat.12904

\section{General rights}

Copyright and moral rights for the publications made accessible in the public portal are retained by the authors and/or other copyright owners and it is a condition of accessing publications that users recognise and abide by the legal requirements associated with these rights.

- Users may download and print one copy of any publication from the public portal for the purpose of private study or research.

- You may not further distribute the material or use it for any profit-making activity or commercial gain

- You may freely distribute the URL identifying the publication in the public portal 
Research paper

\section{Assessing the transport of pharmaceutical compounds in a layered aquifer discharging to a stream}

Nicola Balbarini

Corresponding author: Technical University of Denmark, present address DHI, Agern Alle 5, 2970 Hørsholm, 004552524709, niba@digroup.com,

Majken Frederiksen, present address Rambøll, Copenhagen, Denmark, mjf@ramboll.dk

Vinni Rønde, Department of Environmental Engineering, Technical University of Denmark, Kgs. Lyngby, Denmark, vikar@env.dtu.dk

Ingelise Møller, Department of Groundwater and Quaternary Geology Mapping, Geological Survey of Denmark and Greenland (GEUS), Aarhus C, Denmark, $\underline{\text { ilm@geus.dk }}$

Anne T. Sonne, Department of Environmental Engineering, Technical University of Denmark, Kgs. Lyngby, Denmark

Ursula S. McKnight, Department of Environmental Engineering, Technical University of Denmark, Kgs. Lyngby, Denmark, usmk@env.dtu.dk

Jørn K. Pedersen, Department of Environment and Raw materials, Region of Southern Denmark, Vejle, Denmark, joern.k.pedersen@rsyd.dk

Philip J. Binning, Office for Study Programmes and Student Affairs, Technical University of Denmark, Kgs. Lyngby, Denmark, dtu-graduatedean@dtu.dk

Poul L. Bjerg, Department of Environmental Engineering, Technical University of Denmark, Kgs. Lyngby, Denmark, plbj@env.dtu.dk

\section{Conflict of interest: None}

Key words: Pharmaceutical plume, Groundwater-surface water interaction, Integrated approach, Groundwater modelling, principal component analyses and hierarchical cluster analysis, chlorinated ethenes

\footnotetext{
This article has been accepted for publication and undergone full peer review but has not been through the copyediting, typesetting, pagination and proofreading process which may lead to differences between this version and the Version of Record. Please cite this article as doi: 10.1111/gwat.12904
} 
Article impact statement: Semi-persistent pharmaceutical compounds resulted in long-term groundwater and stream water risks

\section{Abstract}

A groundwater plume containing high concentrations of pharmaceutical compounds, mainly sulfonamides, barbiturates and ethyl urethane, in addition to chlorinated ethenes and benzene was investigated. The contamination originating from a former pharmaceutical industry discharges into a multilayered aquifer system and a downgradient stream. In this study, geological and hydrogeological data were integrated into a numerical flow model to examine identified trends using statistical approaches, including principle component analysis and hierarchal cluster analysis. A joint interpretation of the groundwater flow paths and contaminant concentrations in the different compartments (i.e. groundwater and hyporheic zone) provided insight on the transport processes of the different contaminant plumes to the stream. The analysis of historical groundwater concentrations of pharmaceutical compounds at the site suggested these compounds are slowly degrading The pharmaceutical compounds migrate in both a deep semi-confined aquifer, as well as In the shallow unconfined aquifer, and enter the stream along a $2 \mathrm{~km}$ stretch. This contrasted with the chlorinated ethenes, which mainly discharge to the stream as a focused plume from the unconfined aquifer. The integrated approach developed here, combining groundwater flow modelling and statistical analyses of the contaminant concentration data collected in groundwater and the hyporheic zone, lead to an improved understanding of the observed distribution of contaminants in the unconfined and semi-confined aquifers, and thus to their discharge to the 
stream. This approach is particularly relevant for large and long-lasting contaminant sources and plumes, such as abandoned landfills and industrial production sites, where field investigations may be very expensive.

\section{Introduction}

Surface water and particularly connected groundwater-surface water systems can be impacted by contaminant plumes arising from point sources such as former industrial sites, dry cleaning facilities, gasoline stations and old landfills (Freitas et al., 2015; Conant et al. 2004; Westbrook et al., 2005; Lorah et al., 2009). Understanding the transport and fate processes in groundwater plumes from contaminated sites discharging to streams are a key task for managing stream water quality (Roy and Bickerton, 2011; Sonne et al., 2017).

Microbial biodegradation can successfully reduce contaminant concentrations in groundwater plumes over time; however, the process is often limited to easily biodegradable organic compounds such as petroleum hydrocarbons (Cozzarelli et al., 2010; Essaid et al., 2011). Chlorinated solvents can also be degraded, but the sequential degradation may generate toxic and/or recalcitrant metabolites in the plume (Badin et al., 2016; Chambon et al., 2013; Vogel et al., 1987). Large and long-lasting chlorinated ethene plumes have been observed (Hunkeler et al., 2011), while for petroleum hydrocarbons shorter plumes and more extensive degradation is expected (Essaid et al., 2003). A special concern is complex plumes with co-mingling compounds, such as the ones discharging from landfill sites or industrial production facilities, because the interaction, behavior 
and effect of chemical mixtures in the environment are far from fully understood (Christensen et al., 2001; Bennett et al., 2017).

Pharmaceutical compounds are an increasingly pressing issue for both groundwater and surface water (D'Alessio and Ray, 2016). These compounds have been extensively used in the past decades but are semi-persistent, and their presence has raised concern for the environment and for human health (Boxall, 2004; Thiele-Bruhn and Beck 2005; Fent et al., 2006; Bolong et al., 2009; Madureira et al., 2012; Lapworth et al., 2012; Lapworth et al., 2015; Manamsa et al., 2016). The presence of pharmaceuticals in groundwater has mainly been investigated from wastewater treatment plants, septic tanks, sewage systems and manure (Stuart et al., 2014; Schaider et al., 2013; review by Deo and Halden, 2013; review by D’Alessio and Ray, 2016; Bennett et al., 2017).

Contaminated sites, such as landfills and old factory sites, may also lead to contaminant plumes with high concentrations of pharmaceuticals (e.g. Deo and Halden, 2013; D'Alessio and Ray, 2016). To date, pharmaceutical plumes originating from landfills have only been investigated in a few studies (Eckel et al., 1993; Barnes et al., 2004; Buszka et al., 2009; Holm et al., 1995). As an example, the plume at Grindsted landfill in Denmark discharges more than $1000 \mathrm{~kg} / \mathrm{year}$ of sulfonamides and barbiturates into the surrounding groundwater (Balbarini et al., 2018). The landfill studies reveal that the pharmaceutical compounds seem to pose a severe risk for groundwater and surface water compared to more degradable compounds usually studied at contaminated sites, although some degradation occurred. However, pharmaceutical plumes from industrial production facilities may behave differently since they do not contain a mixture of compounds as diverse as those originating from landfills, where many types of waste (e.g. household waste) rich in organic matter has often been deposited. To our knowledge, only one 
study has focused on antibiotics in a plume originating from a pharmaceutical production site (Bennett et al., 2017).

Thus, complex contaminant plumes originating from sites with semi-persistent compounds can have extensions of several 100 m (e.g. Hunkeler et al. 2011; Bennett et al., 2017). Such large plumes, with time to pass through low permeability layers and contaminate semi-confined aquifers, may have a very complex flow and transport pattern in a near stream layered system, which is currently poorly understood. This is especially true for pharmaceutical plumes originating from production sites, where little is known about degradation processes in the plume.

Therefore, the overall aim of this study is to assess the transport of a contaminant plume discharging to a stream from an old factory site (Grindsted, Denmark) by combining geological, hydrogeological and contaminant data with numerical flow modelling and statistical analyses, including principal component analysis (PCA) and hierarchical cluster analysis (HCA). We specifically investigate transport and long-term behavior of pharmaceutical compounds in the plume by reviewing the fate of the compounds, and analyzing the historical development and current state of the plume. The findings are then used to discuss the attenuation of pharmaceuticals in the plume. Finally, we discuss the use of a combined methodology for assessment of contaminant plumes and the implications for risk assessment at the site.

\section{Study site}

\section{Factory site, groundwater and stream contamination}

Grindsted Factory is a former pharmaceutical production facility located in southern Denmark, which was founded in 1924. The production included sleeping pills and antibiotics, and 
grew significantly in magnitude after World War II. With the increase in production followed an increase in the environmental impact of the factory's activities, until several initiatives during the 1970s reduced the release of contaminants to the environment (Krüger A/S, 1992).

Pharmaceutical compounds (mainly 13 key compounds including sulfonamides, barbiturates and ethyl urethane), chlorinated ethenes and aromatic hydrocarbons (mainly benzene) related to the fac-tory are found in the aquifer system beneath the town of Grindsted. The contaminants have been monitored in groundwater for more than 25 years; however, the geology, hydrogeology and historical data have never been systematically assessed in relation to flow and plume development.

The monitoring of the contaminant concentrations in the groundwater plume reveals that the highest concentrations today are observed from well 1447 to the stream down-gradient of the factory site. Thus, this study focuses on the area, where we see current contaminant plume today as indicated by the numerical model domain in Figure 1. Information on all wells included in this study, and the chemical and hydraulic parameters obtained from each well, is provided in Table S1.

Grindsted Stream is a gaining stream with a catchment area of around $200 \mathrm{~km}^{2}$. The annual average flow is $2000 \mathrm{~L} / \mathrm{s}$ and the stream is $8-12 \mathrm{~m}$ wide and 1-2.5 $\mathrm{m}$ deep (Balbarini et al., 2017). Groundwater and hyporheic zone water samples collected below the streambed showed that groundwater contaminated by pharmaceutical compounds discharges along a $2 \mathrm{~km}$ stretch of the stream (Rasmussen et al., 2016; Sonne et al., 2017). A discharge area (red rectangle in Figure 1) with high groundwater concentrations of benzene, chlorinated ethenes, mainly $c$ DCE (cis-1,2dichloroethene) and vinyl chloride (VC), and pharmaceutical compounds was found (Rønde et al., 2017; Sonne et al., 2017; Balbarini et al, 2018). Outside this area, chlorinated ethenes were only found to enter the stream in low concentrations, in contrast to the pharmaceutical compounds, 
which entered the stream over a larger area (Sonne et al., 2017). Chlorinated ethenes are affected by reductive dechlorination in the strongly reduced parts of the plume (Rønde et al., 2017; Balbarini et al., 2018).

\section{Hydrogeology at the Grindsted factory site}

The 3 D geologic model developed by Maurya et al. (2018) shows a top ca. $10 \mathrm{~m}$ Quaternary meltwater sand layer with an embedded sand till layer (Figure 2). Postglacial freshwater sand and peat deposits overlie the meltwater sand deposits close to the stream. Below this, there is a Miocene Odderup sand layer (Heron et al., 1998; Maurya et al., 2018; Balbarini et al., 2018). The top of the Miocene sand deposits can be found between 30 and $25 \mathrm{~m}$ asl.

A succession of clay and lignite with interbedded sand is present between 25 and $15 \mathrm{~m}$ asl. This succession is ca. $5 \mathrm{~m}$ thick close to the stream and gets thinner away from the stream. At well 1447, the clay rich deposits are less than $0.5 \mathrm{~m}$ thick. Close to the stream, this layer separates the aquifer into a shallow unconfined aquifer and a deep semi-confined aquifer $(>30 \mathrm{~m}$ bgs (below ground surface)). At well 1447 and closer to the contaminated factory site, the clay layer is so thin that only one unconfined aquifer is found.

Additional clay and lignite layers are embedded in the Miocene sand deposits around 10, -15, -20 , and $-30 \mathrm{~m}$ asl. Note, however, that these layer descriptions are based on only 3 boreholes in the model domain and deep boreholes in the surrounding area, including 1425 and 2127 . At ca. $80 \mathrm{~m}$ bgs, a regional and thick confining clay layer is found. Thus, this study will focus only on the aquifer system in the upper $80 \mathrm{~m}$ bgs. 


\section{Fate of pharmaceutical compounds}

It is unusual to observe pharmaceutical compounds in groundwater at concentrations as high as the ones found in this case, and the behavior of the compounds in groundwater is far from being well understood. Therefore, this section summarizes the transport, sorption and degradation properties of 13 key pharmaceuticals (mainly sulfonamides, barbiturates and ethyl urethane) identified in the plume from the factory site (see details in Appendix S1).

The 13 pharmaceutical compounds have low to moderate $\log \mathrm{K}_{\mathrm{ow}}$-values in the range of -2.16 to 2.10 , indicating low affinity for sorption to organic matter. This is supported by a study of the sorption of meprobamate to natural soil, where no significant sorption was observed for sand or medium loam (Lin et al., 2011). Regarding sulfonamides, their sorption potential was found to be quite low in laboratory batch experiments by Białk-BieliDska et al. (2012). Hence, all 13 pharmaceuticals can be considered highly mobile during transport in groundwater. Volatilization is not considered relevant, since the Henry's law constant is not above $0.01 \mathrm{~Pa} \mathrm{~m}^{3} / \mathrm{mol}$ for any of the pharmaceuticals (DTU Food, 2018).

Literature concerning the degradation of the 13 pharmaceuticals is scarce, particularly in groundwater systems. No information has been found about the fate of ethyl urethane, possibly because it is not a common groundwater contaminant. Results for both meprobamate and barbiturates are somewhat conflicting. While one study did not observe degradation of any of the six barbiturates in river water (Peschka et al., 2006), a tank experiment using groundwater determined removal rates for both oxic and anoxic conditions (Burke et al., 2014). Similarly, conflicting results exist for meprobamate (Burke et al., 2014; Lin et al., 2011). In a review of degradation rate constants for emerging organic compounds, Greskowiak et al. (2017) report the 
first order degradation rate of meprobamate degradation to be in the range $0.0001-0.3 \mathrm{~d}^{-1}$ based on three studies and the QSAR model BIOWIN4 (US EPA, 2012). This is a span of three orders of magnitude and demonstrates the scarcity of information and huge variation of results reported.

The degradation mechanisms of sulfonamides were studied by Bennett et al. (2017) in the context of a contaminant plume from a pharmaceutical production site situated above a limestone aquifer. Indications in literature that microbes may utilize sulfonamides as either sources of carbon, nitrogen or sulfur were confirmed in laboratory batch experiments. The addition of nitrate or sulfate did not affect the extent of mineralization of sulfanilamide when no competing source of carbon was present. However, in the presence of toluene, biodegradation of sulfanilamide was inhibited by the addition of nitrate or sulfate, suggesting that sulfonamides are not the preferred source of C, N or S, but that they may be utilized in the absence of a better alternative.

In a laboratory batch experiment with aquifer material, the compound sulfamethoxazole was found to display reversible transformation to the form 4-nitro-sulfamethoxazole under denitrifying conditions (Barbieri et al., 2012). Although not among the 13 key pharmaceuticals, this would certainly indicate that sulfonamides are susceptible to changes in redox conditions, and that complicating factors can affect the results obtained from degradation experiments.

Clearly, the degradation rates and mechanisms of the pharmaceuticals found in the Grindsted factory plume are currently not well documented, however, most existing studies point to considerable persistence to some degradation in groundwater systems. This is in accordance with field observations (Bennett et al., 2017; Hass et al., 2012; Holm et al., 1995). Hence, the pharmaceutical compounds differ from chlorinated ethenes and BTEX released from the factory site in that they can be expected to be semi-persistent. 


\section{Methods}

\section{Hydrogeological data}

Hydraulic heads in boreholes 1447, 1448, 1495, 1996 and 1997 (Figure 1) have been monitored since November 2013 by use of dataloggers and manual measurements. Additional manual measurements were performed periodically at wells 2507, 2508, 2569 and 2570 (Figure 1) during 2016 and 2017. Horizontal hydraulic conductivity values were estimated from slug tests at 78 screens and from the grain size analysis of 56 soil samples collected every $0.5 \mathrm{~m}$ between 0 and $29.5 \mathrm{~m}$ bgs at well 2507 (Table S5 and S6). Data collection and analysis are described by Maurya et al. (2018).

\section{Numerical flow model and set up}

A groundwater flow model was developed using the finite element method implemented in COMSOL Multiphysics, in order to describe the groundwater flow to Grindsted stream (Figure 1). The model applies a free triangular mesh with a total of 941,120 elements and 1,340,628 nodes. It builds on a mathematical formulation described by Balbarini et al. (2017) and implements the $3 \mathrm{D}$ ological model developed by Maurya et al. (2018). A comparison between the layers described by the geological model and the layers implemented in the groundwater flow model is provided in Table 1. For each layer implemented in the groundwater flow model, the hydraulic conductivity used in the model is provided in Table 1. The thin Miocene clay and lignite layers found below 55 $\mathrm{m}$ bgs are not implemented in the hydrogeological model. 
Table 1: Layers described by the geological model for the Grindsted factory site and layers implemented in the groundwater flow model with horizontal hydraulic conductivity (Kh) and vertical hydraulic conductivity $(\mathrm{Kv})$.

\begin{tabular}{|c|c|c|c|c|c|}
\hline $\begin{array}{l}\text { Layers of the } \\
\text { geological model }\end{array}$ & $\begin{array}{c}\text { Layers of the } \\
\text { hydrogeological } \\
\text { model }\end{array}$ & $\begin{array}{c}\text { Layers } \\
\text { no. }\end{array}$ & $\begin{array}{c}\text { Average } \\
\text { thickness } \\
\text { (m) } \\
\end{array}$ & $\mathbf{K h}$ & $\mathbf{K v} / \mathbf{K h}$ \\
\hline $\begin{array}{l}\text { Postglacial } \\
\text { freshwater sand } \\
\text { Postglacial } \\
\text { freshwater peat } \\
\text { Meltwater sand }\end{array}$ & Meltwater sand & 1 & 6.6 & $1.810^{-4}$ & 0.1 \\
\hline Sand till & Sand till & 2 & 1.3 & $6.710^{-6}$ & 0.1 \\
\hline Meltwater sand & Meltwater sand & 3 & 7.3 & $1.810^{-4}$ & 0.1 \\
\hline Miocene sand & Miocene sand & 4 & 2.3 & $1.810^{-4}$ & 0.1 \\
\hline $\begin{array}{l}\text { Miocene clay and } \\
\text { lignite }\end{array}$ & $\begin{array}{l}\text { Miocene clay and } \\
\text { lignite }\end{array}$ & 5 & 2.0 & $1.410^{-6}$ & 0.01 \\
\hline Miocene sand & Miocene sand & 6 & 4.6 & $1.810^{-4}$ & 0.1 \\
\hline $\begin{array}{l}\text { Miocene clay and } \\
\text { lignite }\end{array}$ & $\begin{array}{l}\text { Miocene clay and } \\
\text { lignite }\end{array}$ & 7 & 1.2 & $1.410^{-6}$ & 0.01 \\
\hline $\begin{array}{l}\text { Miocene sand } \\
\text { Miocene clay and } \\
\text { lignite } \\
\text { Miocene sand } \\
\text { Miocene clay and } \\
\text { lignite } \\
\text { Miocene sand } \\
\text { Miocene clay and } \\
\text { lignite } \\
\text { Miocene sand } \\
\text { Miocene clay and } \\
\text { lignite } \\
\text { Miocene sand }\end{array}$ & Miocene sand & 8 & 54.8 & $1.810^{-4}$ & 0.1 \\
\hline
\end{tabular}

The model simulates groundwater flow in both the shallow unconfined aquifer and the deep semi-confined aquifer located in the Miocene formation between 10 to $80 \mathrm{~m}$ bgs. The model assumes steady-state conditions by simulating the average groundwater head during 2014 and 2015. 
This assumption was considered acceptable for describing the transport pathways of semi-persistent pharmaceutical compounds in the contaminant plume at the site over a long period of time, as described in the previous section and in Appendix S1.

Dataloggers installed in the wells closest to the model boundaries showed a maximum yearly change in head of $0.6 \mathrm{~m}$ at the southern boundary and $0.7 \mathrm{~m}$ at the northern boundary during the installation period between November 2013 and September 2017 (from 35.3 to $35.9 \mathrm{~m}$ asl in well 1997 close to the southern boundary and from 36.7-37.2 $\mathrm{m}$ asl in well 1447 close to the northern boundary). The northern and southern boundaries are designated as constant head boundaries, designed using the equipotential map shown in Figure 1. The eastern and western boundaries are fixed head boundaries with a linear head gradient along the boundary. The groundwater head in the northern and southern boundaries is implemented using observations at wells 1447 and 1997 , respectively. A vertical hydraulic gradient was implemented based on the difference in head measured at wells with multiple screens over depth. The geometric mean of the hydraulic conductivity from slug tests and grain size analysis were implemented accordingly to the layer of the model and the value. The horizontal hydraulic conductivity values, the ratio between the horizontal and the vertical hydraulic conductivity and the horizontal and the vertical hydraulic gradients implemented at the model boundaries were calibrated by comparing the simulated groundwater head and the observed groundwater head at eighteen locations.

\section{Chemical data}

Groundwater from 60 screens and water samples collected at 3 locations in the hyporheic zone were included in this study (Table S1). The concentrations of 48 pharmaceutical and 
production-related compounds, mainly ethyl urethane, sulfonamides and barbiturates, were reported (Table S7). Water samples were additionally analyzed for major ions, chlorinated ethenes and benzene. The laboratory methods applied for the chemical analyses are described in Appendix S2. The total concentrations of chlorinated ethenes are expressed as the sum of PCE, TCE, DCE and VC in PCE equivalents [mass/volume]. The contribution of each compound is calculated by multiplying the molar concentration [mole/volume] of each chlorinated ethene compound (e.g. VC) with the molar weight [mass/mole] of PCE.

The historical dataset includes five pharmaceutical or production-related compounds (ethyl urethane, sulfacarbamide, sulfaguanidine, sulfanilamide and sulfanilic acid) from four wells (1425, 1335, 1495 and 1448) sampled in 1988-1990 (Table S8). Chemical analyses of groundwater samples from the plume were few before the late 1980s (Krüger A/S, 1992) and rarely included degradation products from PCE/TCE (VC and cis-DCE) before 1990. Furthermore, the location and composition of the plume was not well known until the $2000 \mathrm{~s}$, and this affected the choice of sampling points and chemical analyses. Therefore, assessment of the plume before 1988 is infeasible. Chemical analyses of historical samples were made by different commercial laboratories.

\section{Statistical analyses}

A statistical comparison of data from respectively 1988-1990 and 2012-2016 was conducted. For this purpose, points where concentrations were below detection were assigned a value of 0.1 $\mu \mathrm{g} / \mathrm{L}$. It should be noted that detection levels were much higher in the early time period, as high as $100 \mu \mathrm{g} / \mathrm{L}$, whereas they are not above $0.5 \mu \mathrm{g} / \mathrm{L}$ in the more recent time period. A paired two-sample $t$-test for means, one tail, was performed in Microsoft Excel. However, since the data is strongly 
skewed towards the lower values, a log-transformation (base 10) was made in order to comply with the assumption of normalized data. With five pharmaceuticals measured in five screens, a total of 25 observations are available for each time period at the factory site. Near the stream, five pharmaceuticals analyzed in 13 screens produces 65 observations for each time period.

Principal component analysis (PCA) was used to group and thus characterize information related to borehole (groundwater) and hyporheic zone data and their associated water quality with respect to the pharmaceutical compounds in the model focus area. Ordination techniques, such as PCA, can be combined with cluster analyses (here, hierarchical cluster analysis (HCA) was used, applying a SIMilarity PROFile analysis (SIMPROF), $\mathrm{p}<0.05$ ) to obtain a better interpretation of the ordination diagrams (Ramette, 2007). The statistical analyses were performed in PRIMER. Data used for the PCA analysis were transformed using fourth root, while Euclidian distance was used as a resemblance measure before performing HCA.

\section{Results and discussion}

\section{Hydrogeology}

The vertical distribution of hydraulic heads is shown in Figure 2 at five wells close to the stream $(1495,2570,2507,2508$ and 1448) and at a well on the northern boundary of the investigated area (1447). At the wells close to the stream, the hydraulic head in the meltwater sand is lower compared to the hydraulic head in the Miocene formation below the lignite/clay layer. Contrastingly, at well 1447, all three screens show similar groundwater head. A similar trend can be observed at two wells close to the factory site: 1425 and 2127 (Figure S1). The difference in groundwater head between the meltwater sand and the Miocene sand formation suggests that the 
two layers are hydraulically disconnected near the stream, while the lack of a vertical hydraulic gradient at well 1447 suggests that the two layers are well connected at this location. Close to the stream, the sequence of lignite and clay is up to $10 \mathrm{~m}$ thick, while in the northern part of the study area, it is thinner and discontinuous. This may explain the small difference in groundwater head between the meltwater and the Miocene sand observed at well 1447 (Figure 2), as well as at the factory site (Figure S1).

The groundwater head was measured at several screens located at different depths in the Miocene sand, at wells 1495, 2570, 2507, 1448 and 1447. The measured hydraulic head (blue dots in Figure 2) is similar in all screens located in the Miocene sand, independent of the depth. Thus, the clay and lignite layers embedded in the Miocene sand may not be a hydraulic barrier for groundwater flow.

These trends in the hydraulic head are consistent over time and the temporal changes in groundwater head monitored in screens located in the shallow unconfined aquifer at wells 1448 and 1495 are similar to changes in stream water level (Balbarini et al., 2017). Thus, groundwater flow conditions can be described by assuming a steady-state simulation. Temporal changes in the screens located in the Miocene sand are smoother and similar to groundwater head changes in the three screens at well 1447. This confirms that the lignite/clay layer at ca. $25 \mathrm{~m}$ asl (Figure 2c) behaves as a hydraulic barrier close to the stream.

Two aquifers are considered based on the $3 \mathrm{D}$ geological model and on groundwater head data: an unconfined aquifer located in the top $15 \mathrm{~m}$ bgs ( $25 \mathrm{~m}$ asl) mainly in the meltwater sand, and a semi-confined aquifer located between 25 and $80 \mathrm{~m}$ asl, in the Miocene sand. Thin Miocene clay 
layers below $10 \mathrm{~m}$ asl were not included in the groundwater flow model because a small effect on the flow is assumed.

\section{Simulation of groundwater flow}

The groundwater flow model can properly describe the groundwater fluxes through the model boundaries, with a water balance error lower than $4.5 \%$. A full water balance for the mathematical model is provided in Table S9. The simulated groundwater head was compared with the observed groundwater head. A good correlation between the simulated and measured hydraulic heads (in wells not used for defining the boundary conditions) is obtained (Figure S2) with a correlation coefficient of 0.95 , indicating that the groundwater flow model can describe the distribution of hydraulic heads well. The good correlation can also be seen in Figures $2 b$ and $2 c$, which show that simulated changes in groundwater head over depth (in five wells) matches the observed changes. Thus, the model can simulate the distribution of hydraulic heads in both the deep, semi-confined and upper, unconfined aquifers.

At the northern boundary no vertical gradient is shown by the equipotential lines, neither in the unconfined nor in the semi-confined aquifer (Figure 2). When moving closer to the stream, a vertical upward gradient is present in the unconfined aquifer and in the upper part of the semiconfined aquifer, but not in the lower part of the confined aquifer. The clay and lignite layers, separating the two aquifers, display steep upward hydraulic gradients, especially close to the stream. Consequently, the groundwater streamlines are mainly horizontal in the deep semi-confined aquifer, while they show an upward flow to the stream in the unconfined aquifer. In the unconfined aquifer, the average of the simulated horizontal groundwater pore velocity is $82 \mathrm{~m} /$ year, assuming a porosity 
of 0.37 (Rügge et al, 1999). In the semi-confined aquifer, the average of the simulated horizontal flow velocity is $32 \mathrm{~m} /$ year and it increases when moving closer to the unconfined aquifer. It is important to highlight that these estimated values of flow velocities are highly sensitive to changes in the hydraulic conductivity in the aquifers. The hydraulic conductivity was derived from slug test measurements and calibrated by comparing the simulated and observed hydraulic heads. However, this comparison was more sensitive to the ratio of hydraulic conductivities between the sandy and clayey layers, rather than the hydraulic conductivity value in the sandy aquifers.

In Figure 3, the simulated groundwater flow paths and hydraulic equipotential lines are shown for the unconfined and semi-confined aquifers. The groundwater flow direction in both aquifers is towards the stream; however, the flow field is different. The magnitude of the hydraulic gradient is much higher in the unconfined aquifer compared to the semi-confined aquifer, as indicated by the density of the hydraulic equipotential lines. While groundwater discharges to the stream from the unconfined aquifer at angles close to 90 degrees with respect to the stream, the groundwater flow paths in the semi-confined aquifer are different: here groundwater flows toward the stream, but instead of discharging to the stream it changes course and continues along a flow path parallel to the

stream. These results are supported by the observed groundwater head within the model area (see close-ups in Figure 3), where the groundwater flow directions shown are estimated by the method developed by Devlin and Schillig (2017).

\section{Evaluation of flow paths and chemical patterns in groundwater and stream discharge}

PCA combined with HCA was used to investigate the differences in the concentrations and the spatial distributions of 13 pharmaceutical compounds (see Table S2, Table S3 and Table S4 for 
properties, use and structure of these compounds). Groundwater concentrations at 14 screens located in the semi-confined aquifer and 9 screens located in the unconfined aquifer were used. Hyporheic zone concentrations at 3 locations were also included in the analysis of the unconfined aquifer. The pharmaceutical compounds were selected to include the compounds found in the highest concentrations during the field campaigns in 2016 All screens with no or low concentrations ( $<20 \mu \mathrm{g} / \mathrm{L}$ for all compounds) were excluded from the PCA and HCA.

Principal components 1 and 2 explained $73 \%$ of the variance in the data of the semi-confined aquifer, while they explained $69 \%$ of the variance in the data of the unconfined aquifer. The results of the statistical analyses (Figure S4), grouping wells according to similarities in contaminant composition and concentrations, have been combined with the results of the groundwater flow model in Figure 4. Thus, the groundwater flow model may be used to explain the significant correlations identified by the statistical evaluation.

In the unconfined aquifer, all wells show a similar distribution of pharmaceutical compounds and no statistical differences could be found by the statistical analysis (Figure S4a). All wells shown in Figure 4a have high concentrations of the investigated pharmaceutical compounds, up to e.g. $5,700 \mu \mathrm{g} / \mathrm{L}$ for ethyl urethane.

The plume of pharmaceutical compounds in the unconfined aquifer is not present at well 1495, which is therefore not shown in Figure 4a. This can be explained by the groundwater flow paths. The groundwater streamlines originating from the factory site discharge to the stream east of (i.e. upstream of) well 1495 (see Fig. 1). Furthermore, very low contaminant concentrations were detected at well 1447 (located east of/upstream of well 1495) in the unconfined aquifer. The pharmaceutical plume may thus be located down-gradient of well 1447, in contrast to the 
pharmaceutical plume in the semi-confined aquifer which is also present at well 1447 (see Figure 4b). It is important to highlight that high concentrations of pharmaceuticals (up to $620 \mu \mathrm{g} / \mathrm{L}$ of butalbital) were found at only one well at the contaminant source (2127) and, at this location, no statistical difference was found with the distribution of pharmaceuticals in wells close to the stream.

According to the streamlines in the unconfined aquifer and the statistical analysis, high concentrations of contaminants originating from the factory site are discharging to the stream near the stream bend located in the middle of the modelled area. Thus, the stream bend is a hotspot area where a substantial part of the contaminant plume in the unconfined aquifer is entering the stream. This is supported by samples collected in groundwater upstream of the stream bend (e.g. 2568 and 2508), in the hyporheic zone (st 4, 6 and 8) and in stream water (see Rønde et al., 2017; Sonne et al., 2017).

In the semi-confined aquifer, the plume originating in the northern part of the factory site migrates through well 1447 and then through 1495 (Figure 4b). This is confirmed by the statistical analysis, which found significant similarities between well 1447 and well 1425 located at the factory site (Figure S4b). In contrast, the other wells (1448, 2507, N1 and 2568) did not show a similar composition of the pharmaceutical compounds. Wells which presented a statistically different distribution of pharmaceuticals compared to all other wells were not included in Figure $4 \mathrm{~b}$.

The plume originating from the southern part of the factory site may be characterized by a different distribution of pharmaceuticals compared to the northern one. This is supported by the statistical similarities between wells N1 and 2507, which are down-gradient of the southern part of the factory site (Figure 4b). However, no recent groundwater samples collected in the southern part of the source zone could be used to support this. Historical studies which looked at the distribution 
of contaminants at the factory site identified a hotspot area in the northern part of the factory with a different composition compared to the southern part of the factory (Krüger, 1992). This reinforces the presence of different compositions in the contaminant plume near the stream.

The most down-gradient well included in this study is 1495 . Here, concentrations up to 880 $\mu \mathrm{g} / \mathrm{L}$ of sulfanilamide are found around $15 \mathrm{~m}$ asl. The groundwater flow model suggests that the contaminant plume found at this location would flow further down-gradient, leading to a potential risk to the semi-confined aquifer and, eventually for down-gradient stream reaches. This may explain the presence of pharmaceutical compounds discharging to the stream along a $2 \mathrm{~km}$ stream stretch, as suggested by hyporheic zone and stream water data (Sonne et al., 2017). This differs from the chlorinated ethene and petroleum hydrocarbon plume which mainly enters the stream along the stream bend. It is important to highlight that chlorinated ethenes and petroleum hydrocarbons are also found in high concentrations at well 1495, up to $2076 \mu \mathrm{g} / \mathrm{L}$ chlorinated ethenes expressed as PCE equivalents and $290 \mu \mathrm{g} / \mathrm{L}$ benzene. However, other processes such as degradation may take place in the semi-confined aquifer, leading to different patterns in the pharmaceutical plume compared to the chlorinated ethene and petroleum hydrocarbon plume. This is further investigated in the following sections by looking at the historical data, redox conditions and degradation processes.

\section{Plume development 1988-1990 to 2012-2016}

The bulk of the groundwater contamination from Grindsted factory probably originates due to leakage from storage and production facilities during the 1960s and 1970s, 50-70 years ago, and hence, changes in the plume location and composition are expected. Figure 5 shows the 
distributions over depth for selected compounds (ethyl urethane, sulfanilamide and benzene) measured in 1988-1990. Unfortunately, the historical analysis of chlorinated ethenes did not include all degradation products (cis-DCE, VC), and therefore, total chlorinated ethenes cannot be calculated for this period. In contrast to the recent results from 2012-2016 (Figure 6), none of the selected compounds were found in the wells near the stream in 1988-1990 (Figure 5), aside from $4.4 \mu \mathrm{g} / \mathrm{L}$ benzene in screen 1448-6. In 2015-2016, on the other hand, the concentrations in screen 1447-2 were as high as $1713 \mu \mathrm{g} / \mathrm{L}$ chlorinated ethenes, $880 \mu \mathrm{g} / \mathrm{L}$ sulfanilamide, and $290 \mu \mathrm{g} / \mathrm{L}$ benzene.

Thus, due to groundwater flow, the contamination released at Grindsted Factory has been carried towards Grindsted stream over time. Figure 5 shows that, in 1988-1990, the contaminant plume originating at the factory site had reached well 1447, but not the stream. In contrast, as observed from Figure 6, the level of contamination has since increased in wells 1495 and 1448. This is in line with the average simulated groundwater flow velocity, which predicts a travel time from the source to well 1447 and 1495 of, respectively, 22 and 47 years in the semi-confined aquifer and of, respectively, 8 and 18 years in the shallow aquifer. The travel time estimation is based on the assumption that the average groundwater flow velocity is constant between the source and well 1495, even though the model domain includes only about half of this distance. The following section will further investigate this spatial shift of the plume over time, focusing on the pharmaceutical compounds.

The two plots in Figure 7 compare all measurements of the two periods with one another. All 'below detection' measurements have been assigned a value of $0.1 \mu \mathrm{g} / \mathrm{L}$. Points above the 1-1 line indicate a decrease over time, i.e., the early measurements are higher than the later measurements. 
Conversely, points below the 1-1 line suggest that the concentrations measured at recent points in time were higher than the early concentrations in the same well.

At the factory site (Fig. 7a), most points fall above the 1-1 line. Furthermore, all the detections in the high range, over $1000 \mu \mathrm{g} / \mathrm{L}$, are made in the early period. Near the stream (Fig. 7b), this is reversed: only three detections of pharmaceuticals (sulfanilic acid) were made in 19881990, whereas several measurements over $100 \mu \mathrm{g} / \mathrm{L}$ were made in 2012-2016. Hence, the contaminant plume seems to have changed both in location and intensity over the intervening $25-28$ years.

The statistical analysis, testing the suggested change in plume location, supports this finding. The p-value of the paired $t$-test is $5.2 \cdot 10^{-5}$ when comparing the two periods at the factory site, while it is $7.5 \cdot 10^{-7}$ for the wells near the stream at two different time periods. Hence, the difference between the two periods is statistically significant in both the case of the factory site and near the stream.

In conclusion, two key observations can be made regarding the development of the Grindsted Factory site contaminant plume between 1988-1990 and 2012-2016. Firstly, the source seems to be depleted and the current hotspot is somewhere between well 1447 and Grindsted stream. Secondly, the concentration levels in the plume have been reduced by about a factor of 10 , although there are variations for individual compounds.

\section{Attenuation of pharmaceuticals in the plume at the Grindsted factory site}

As demonstrated in Figure 7 and discussed in the previous section, a substantial attenuation of pharmaceuticals has occurred in the aquifer from 1988-1990 to 2012-2016. This attenuation can be 
due to depletion of the source, and to attenuation processes such as dispersion, dilution, sorption and degradation. The effect of the different attenuation processes cannot be distinguished in this dataset, even though we observe some interesting attenuation patterns in the plume for pharmaceutical compounds. Since the literature is so scarce on pharmaceutical compounds in aquifers, we find it useful to discuss these observations in more detail.

The reduced conditions in the plume (Figure S3) are most likely driven by degradation of hydrocarbons, and the resultant redox conditions may in turn affect the degradation potential of the pharmaceutical compounds. The review of the fate of pharmaceuticals in Appendix S1 showed that the presence of NVOC, nitrate and sulfate may inhibit microbial degradation of sulfonamides. The concentration of NVOC is generally in the range of 1-15 mg/L. Considering that the background level is 1-3 mg/L (Bjerg et al., 1995), the concentration of NVOC can be characterized as slightly elevated. Since nitrate is depleted aside from the upper few meters and NVOC concentrations are close to background values, sulfate is most likely to influence the degradation potential. It is therefore interesting that the highest concentrations of sulfanilamide occur where the concentrations of sulfate are also highest: in screens 1-5 of well 1495 (west of the stream bend) and above the confining layer in well 2507/08 (at the stream bend). Assuming that degradation is the cause for the low sulfonamide concentrations in the eastern side of the plume, this indicates that the presence of sulfate may inhibit microbial degradation, as suggested by Bennet et al. (2017).

In summary, observations from the Grindsted factory plume indicate that degradation of sulfonamides may occur in a groundwater system. However, natural degradation is slow and unlikely to eliminate the risk from a pharmaceutical contaminant plume. The literature review suggests that the degradation of pharmaceutical compounds in groundwater aquifers depends on the 
redox conditions, sulfate concentrations and dissolved organic carbon. However, the degradation processes for pharmaceutical Grindsted factory site plume are poorly understood, and further studies are in general needed to understand the fate of pharmaceuticals in contaminated aquifers.

\section{Integrated approaches to support risk assessment}

\section{Application of the integrated approach}

The combined analysis of concentration data, taken from boreholes located in the shallow and deep aquifers, hyporheic zone and stream water, together with simulated groundwater flow paths to the stream could provide a more holistic interpretation of the contaminant distribution in the different water compartments. This new understanding of the aquifer system could then explain the presence of pharmaceuticals discharging to the stream along a much longer stream stretch compared to chlorinated ethenes and petroleum hydrocarbons. The results showed the importance of accounting for the contribution of contaminant plumes originating from deep semi-confined aquifers, as well as shallow unconfined aquifers to streams. This contribution is particularly relevant for large and long-lasting contaminant sources and plumes, such as abandoned landfills and lustrial production sites, where contaminant plumes have sufficient time to migrate through low permeability layers.

In order to account for the contribution of contaminant plumes in deep ( $>30-50 \mathrm{~m}$ bgs) semiconfined aquifers, deep drillings are required. The costs of drilling increase with depth and thus the number of deep drillings available for delineating deep contaminant plumes is often not sufficient. Moreover, in the case of pharmaceutical compounds, the costs for analytical analyses are also high, so it is even more challenging to have a sufficient number of drillings combined with chemical 
analyses to describe the distribution of contaminants needed for populating a reactive solute transport model with data.

In this study, we concluded that the few wells available did not permit the development of a numerical model for simulating the contaminant plumes. Lapworth et al. (2013) described the use of a multi-technique methodology, which combined the use of different field techniques for investigating nutrient processes with the hydrological modelling. Instead, we developed a hydrogeological understanding based on the available data and incorporated this into a groundwater flow model, and then combined it with statistical analyses of the distributions of chemical compounds collected at the available boreholes/streambed stations. This approach is in line with the use of microorganic fingerprinting for understanding transport processes in groundwater presented by Stuart et al. (2014). Due to the chemical heterogeneity and extension of the Grindsted factory source, PCA and HCA were used as a supporting tool to compare the distribution of target contaminants at different locations.

The method relies on the assumption that the compounds migrate with groundwater and are not or only slowly degrading, which is the case for the pharmaceuticals considered in this study. The implementation of this method for other xenobiotic compounds may be site-specific, but for large, heterogeneous sources with many compounds, the method can be very useful. Note that degradation will not be a limitation as long as the compounds remain, however, it may be difficult to apply the method if the composition of compounds in the plume changes due to e.g. sequential degradation. For instance, the method could not be applied for the chlorinated ethenes due to reductive dechlorination taking place in the aquifer somewhere between the source and the stream (Rønde et al., 2017; Balbarini et al., 2018). 


\section{Implications for risk assessment}

The results of our study suggest that groundwater plumes originating from contaminated sites, such as former industrial sites and landfills, can be an important contributor to the concentrations of pharmaceuticals found in streams (see also Sonne et al., 2017). Thus, pharmaceuticals could be overlooked compounds belonging to groundwater-sourced contaminants contributing to the urban stream syndrome (Walsh et al., 2005; Roy and Bickerton, 2011). This would have implications for the monitoring and remediation of sites contaminated by pharmaceutical compounds, and for the restoration of groundwater and streams.

The presence of chlorinated ethenes and pharmaceuticals in the deep aquifer near the stream (well 1495) indicates that the deep semi-confined aquifer may also be contaminated downstream of the study area, especially with persistent and semi-persistent compounds, such as the pharmaceuticals. The risk can be extended to the unconfined aquifer and to the stream due to the presence of a steep vertical hydraulic gradient in the upper part of the semi-confined aquifer and in the unconfined aquifer (Cremeans et al., 2018). A detailed geological model should be developed further west of the model domain in order to investigate the continuity and the thickness of the sequence of clay layers separating the unconfined and deep aquifers, however, this will require new boreholes in that area.

In addition to the peak in concentration located at the bend in the center of the model domain, concentrations of pharmaceuticals in the stream are characterized by several peaks distributed along a $2 \mathrm{~km}$ stretch, both upstream and downstream of the model domain presented here (Sonne et al., 2017). This can be explained by the groundwater flow paths in both the unconfined and semi- 
confined aquifers. If new boreholes with multiple screens over depth were located further west of the model domain, chemical analysis can identify the origin of the contamination.

Chlorinated ethenes mainly show a major discharge at the stream bend. This difference may be explained by the fact that the chlorinated ethene plume is predominantly found in the unconfined aquifer close to the stream. Thus, plume migration is dependent on the flow paths in the unconfined aquifer. On the other hand, the pharmaceutical plume is present in both the unconfined and deep semi-confined aquifers. In addition, reductive dechlorination is taking place at the site (Rønde et al., 2017; Balbarini et al., 2018), while observations suggest that the pharmaceutical compounds are non- or only slowly degrading at the site, especially in the deep aquifer. The groundwater flow path in the deep semi-confined aquifer indicates that the plume migrates along a flow path parallel to the stream, and consequently, pharmaceutical compounds are discharging to the stream over a longer stream reach.

\section{Conclusions}

The main groundwater transport paths of a pharmaceutical plume originating from the

Grindsted factory site and discharging to Grindsted stream were investigated in this study. The contaminant concentration data points were considered too scarce compared to the size and the age of the contaminant plume to develop a numerical transport model. Instead, a numerical groundwater flow model was combined with statistical analyses of pharmaceutical contaminant concentrations. This provided a novel understanding of the transport of the contaminant plume towards Grindsted stream. Water quality samples collected in the hyporheic zone and in the stream supported the new understanding based on groundwater samples. Analysis of the documented degradation of the 
compounds and of the historical development of the plume suggested that degradation of some pharmaceutical compounds may occur depending on the redox conditions, sulfate concentrations and dissolved organic carbon. However, the degradation processes of pharmaceutical compounds in groundwater in general, and in the Grindsted factory site plume are poorly understood; further studies are warranted.

At the Grindsted factory site, semi-persistent pharmaceutical compounds resulted in a longterm risk of both groundwater and stream water over a large area. The presence of a layered aquifer enhanced the spreading of the contaminant plume in groundwater, and subsequently, the discharge areas to the stream.

\section{Acknowledgements}

This study was supported by the research project GEOCON, Advancing GEOlogical, geophysical and CONtaminant monitoring technologies for contaminated site investigation (contract 1305-00004B). The funding for GEOCON is provided by Innovation Fund Denmark. Special thanks to our colleagues at DTU environment, namely Bent H. Skov, Jens S. Sørensen, Flemming Møller and Erik R. Lange for assistance in the field. Thanks to Executive Editor, Professor Robert Schincariol, Professor Daren Gooddy, and two anonymous reviewers for their helpful comments. Special thanks also to our partners in the GEOCON project who collected and analyzed geophysical data and were part of useful discussions about the site: Pradip K. Maurya, Gianluca Fiandaca, Anders V. Christiansen and Esben Auken from HydroGeophysics Group, Department of Geoscience, Aarhus University. 
Additional Supporting Information may be found in an online document that contains appendix S1 and S2, figures S1 through S4 and tables S1 through S9 as referenced in the text above.

Please note: "Supporting Information" is generally not peer reviewed. Wiley is not responsible for the content or functionality of any supporting information supplied by the authors. Any queries (other than missing materials) should be directed to the corresponding author.

\section{References}

Badin, A., Broholm, M. M., Jacobsen, C. S., Palau, J., Dennis, P., and Hunkeler, D. (2016). Identification of abiotic and biotic reductive dechlorination in a chlorinated ethene plume after thermal source remediation by means of isotopic and molecular biology tools. Journal of Contaminant Hydrology, 192, 1-19. doi:10.1016/j.jconhyd.2016.05.003

Balbarini, N., Boon, W. M., Nicolajsen, E., Nordbotten, J. M., Bjerg, P. L., and Binning, P. J. (2017). A 3-D numerical model of the influence of meanders on groundwater discharge to a gaining stream in an unconfined sandy aquifer. Journal of Hydrology, 552, 168-181. DOI: $10.1016 /$ j.jhydrol.2017.06.042

Balbarini, N., Rønde, V., Maurya, P., Fiandaca, G., Møller, I., Erik Klint, K., and Bjerg, P. L. (2018). Geophysics based contaminant mass discharge quantification downgradient of a landfill and a former pharmaceutical factory. Water Resources Research, 54, 5436-5456. https://doi.org/10.1029/2017WR021855 
Barbieri, M., Carrera, J., Carlos, A., Sanchez-Vila, X., Licha, T., Nödler, K., Osorio, V., Pérez, S., Köck-Schmulmeyer, M., López de Alda, M., and D. Barceló (2012). Formation of diclofenac and sulfamethoxazole reversible transformation products in aquifer material under denitirifying conditions: batch experiments. Science of the Total Environment, 426, 256-63. https://doi.org/10.1016/j.scitotenv.2012.02.058

Barnes, K. K., Christenson, S. C.,Kolpin, D. W., Focazio, M. J., Furlong, E. T., Zaugg, S. D., and Barber, L. B. (2004). Pharmaceuticals and other organic waste water contaminants within a leachate plume downgradient of a municipal landfill. Ground Water Monitoring and Remediation, 24(2), 119-126.

Bennett, K. A., Kelly, S. D., Tang, X., and Reid, B. J. (2017). Potential for natural and enhanced attenuation of sulphanilamide in a contaminated chalk aquifer. Journal of Environmental Sciences, 62, 39-48. https://doi.org/10.1016/j.jes.2017.08.010

Białk-BieliDska, A., Marszkowska, J., Mrozik, W., Bielawska, A., Koßdziejska, M., Palavinskas, R., Stepnowski, P., and Kumirska, J. (2012). Sulfadimethoxine and sulfaguanidine: Their sorption on natural soils. Chemosphere. 86:1059-1065. doi:10.1016/j.chemosphere.2011.11.058

Bjerg, P. L., Rügge, K., Pedersen, J. K., and Christensen, T. H. (1995). Distribution of redoxsensitive groundwater quality parameters downgradient of a landfill (Grindsted, Denmark). Environmental Science \& Technology. 29(5):1387-1397. doi:10.1021/es00005a035 
Bolong, N., Ismail, A. F., Salim, M. R., and Matsuura, T. (2009), A review of the effects of emerging contaminants in wastewater and options for their removal, Desalination, 239(13), 229-246 https://doi.org/10.1016/j.desal.2008.03.020

Boxall A. B. A. (2004), The environmental side effects of medication, EMBO Rep, 5(12), 1110-1116. DOI 10.1038/sj.embor.7400307

Burke, V., Richter, D., Hass, U., Duennbier, U., Gresowiak, J., and Massmann, G. (2014). Redox-dependent removal of 27 organic trace pollutants: compilation of results from tank aeration experiments. Environmental Earth Science. 71:3685-3695. doi:10.1007/s12665$013-2762-8$

Buszka, P. M., Yeskis, D. J., Kolpin, D. W., Furlong, E. T., Zaugg, S. D., and Meyer, M. T. (2009). Waste-Indicator and Pharmaceutical Compounds in Landfill-Leachate-Affected Ground Water near Elkhart, Indiana, 2000-2002. Bulletin of Environmental Contamination and Toxicology, 82(6), 653-659. doi:10.1007/s00128-009-9702-z

Chambon, J. C., Bjerg, P. L., Scheutz, C., Bælum, J., Jakobsen, R. and Binning, P. J. (2013), Review of reactive kinetic models describing reductive dechlorination of chlorinated ethenes in soil and groundwater. Biotechnol. Bioeng., 110: 1-23. doi:10.1002/bit.24714

Christensen, T.H., Kjeldsen, P., Bjerg, P.L., Jensen, D.L., Christensen, J.B., Baun, A., Albrechtsen,H.-J., and Heron, G., Biogeochemistry of landfill leachate plumes, Appl. Geochem., 2001 16,659-718. https://doi.org/10.1016/S0883-2927(00)00082-2

Conant, B., Cherry, J.A., and Gillham, R.W., (2004), A PCE groundwater plume discharging to a river: Influence of the streambed and near-river zone on contaminant distributions. Journal of Contaminant Hydrology, 73, 249-279. doi:10.1016/j.jconhyd.2004.04.001 
Cozzarelli, I. M., Bekins, B. A., Baedecker, M. J., Aiken, G. R., Eganhouse, R. P., and Tuccillo, M. E. (2010). Progression of natural attenuation processes at a crude-oil spill site: I. Geochemical evolution of the plume. Journal of Contaminant Hydrology, 53,(34):369-385. doi:10.1016/S0169-7722(01)00174-7

Cremeans, M. M., Devlin, J. F., McKnight, U. S., and Bjerg, P. L. (2018). Application of new point measurement device to quantify groundwater-surface water interactions. Journal of contaminant hydrology, 211, 85-93. https://doi.org/10.1016/j.jconhyd.2018.03.010

D'Alessio M., and C. Ray (2016), Pharmaceuticals and Groundwater Resources, Emerging Issues in Groundwater Resources, A. Fares (ed.), Advance in Water Security, Springer, doi:10.1007/978-3-319-32008-3_5.

Deo, R. P., and Halden, R. U. (2013). Pharmaceuticals in the Built and Natural Water Environment of the United States. Water, 5(3), 1346. doi:10.3390/w5031346

Devlin, J. F. and Schillig, P. C. (2017). HydrogeoEstimatorXL: an Excel-based tool for estimating hydraulic gradient, magnitude and direction. Hydrogeology Journal, 25:867875. doi:10.1007/s10040-016-1518-4

DTU Food (2018). Danish QSAR Database. http://qsardb.food.dtu.dk/db/index.html (Updated: n.d., extracted: 12-04-2018).

Eckel, W. P., Ross, B., and Isensee, R. K. (1993). Pentobarbital found in ground water. Groundwater, 31: 801-804. https://doi.org/10.1111/j.1745-6584.1993.tb00853.x

Essaid, H. I., Cozzarelli, I. M., Eganhouse, R. P., Herkelrath, W. N., Bekins, B. A., and Delin, G. N. (2003). Inverse modeling of BTEX dissolution and biodegradation at the Bemidji, 
MN crude-oil spill site. Journal of Contaminant Hydrology, 67(1-4), 269-299. https://doi.org/10.1016/S0169-7722(03)00034-2

Essaid, H. I., Bekins, B. A., Herkelrath, W. N., and Delin, G. N. (2011). Crude oil at the Bemidji site: 25 years of monitoring, modeling, and understanding. Groundwater 49(5), 706-726. doi:10.1111/j.1745-6584.2009.00654.x

European Medicines Agency (2012). European Medicines Agency recommends suspension of marketing authorisation of meprobamate-containing medicines in the European Union. http://www.ema.europa.eu/ema/index.jsp?curl=pages/news_and_events/news/2012/01/ne ws_detail_001427.jsp\&mid=WC0b01 ac058004d5c1 (Updated: 20-01-2012, retrieved: 20-04-2018).

Fent K., A. A. Weston, and D. D. Camidana (2006), Ecotoxicology of human pharmaceuticals, Aquat Toxicol, Vol. 76(2), Pages 122-159.

Freitas, J. G., M. O. Rivett, R. S. Roche, M. Durrant, C. Walker, and J. H. Tellam (2015), Heterogeneous hyporheic zone dechlorination of a TCE groundwater plume discharging to an urban river reach, Science of the Total Environment, Vol 505, Pages 236-252. https://doi.org/10.1016/j.scitotenv.2014.09.083

GEUS (2018). National well database (Jupiter) [National boringsdatabase (Jupiter)]. http://www.geus.dk/produkter-ydelser-og-faciliteter/data-og-kort/nationalboringsdatabase-jupiter/ (Updated: n.d., extracted: 05-07-2018)

Greskowiak, J., Hamann, E., Burke, V., Massmann, G. (2017). The uncertainty of biodegradation rate constants of emerging organic compounds in soil and groundwater - 
A compilation of literature values for 82 substances. Water Research, 126, 122-133. https://doi.org/10.1016/j.watres.2017.09.017

Hass, U., Dünbier, U., and Massmann, G. (2012). Occurrence of psychoactive compounds and their metabolites in groundwater downgradient of a decommissioned sewage farm in Berlin (Germany). Environmental Science and Pollution Research. 19:2096-2106. https://doi.org/10.1007/s11356-011-0707-x

Heron, G., P. L. Bjerg, P. Gravesen, L. Ludvigsen, and T. H. Christennsen (1998), Geology and sediment geochemistry of a landfill leachate contaminated aquifer (Grindsted, Denmark), Journal of Contaminant Hydrology, 29, 301-317. doi:10.1007/s11356-011$0707-\mathrm{x}$

Holm, J. V., Rügge, K., Bjerg, P. L., and Christensen, T. H. (1995). Occurrence and distribution of pharmaceutical organic compounds in the groundwater downgradient of a landfill (Grindsted, Denmark). Environmental Science \& Technology, 29(5), 1415-1420. doi:10.1021/es00012a031

Hunkeler, D., Abe, Y., Broholm, M. M., Jeannottat, S., Westergaard, C., Jacobsen, C. S., Aravena, R., and P. L. Bjerg (2011). Assessing chlorinated ethene degradation in a large scale contaminant plume by dual carbon-chlorine isotope analysis and quantitative PCR. Journal of Contaminant Hydrology, 119(1-4), 69-79. doi:10.1016/j.jconhyd.2010.09.009 Krüger A/S (1992), In Danish, Grundvandsforurening ved Grindsted Products frabiksanlæg I Grindsted, Technical report, Krüger A/S, Søborg, Denmark. 
Lapworth, D. J., Baran, N., Stuart, M. E., \& Ward, R. S. (2012). Emerging organic contaminants in groundwater: A review of sources, fate and occurrence. Environmental Pollution, 163, 287-303. https://doi.org/10.1016/j.envpol.2011.12.034

Lapworth, D. J., Gooddy, D. C., Kent, F., Heaton, T. H. E., Cole, S. J., \& Allen, D. (2013). A combined geochemical and hydrological approach for understanding macronutrient $\begin{array}{lllll}\text { sources. } & \text { Journal } & \text { of }\end{array}$ https://doi.org/10.1016/j.jhydrol.2013.07.006

Lapworth, D. J., Baran, N., Stuart, M. E., Manamsa, K., \& Talbot, J. (2015). Persistent and emerging micro-organic contaminants in Chalk groundwater of England and France. Environmental Pollution, 203, 214-225. https://doi.org/10.1016/j.envpol.2015.02.030

Lin, K., Bondarenko, S., and Gan, J. (2011). Sorption and persistence of water-borne psychoactive and antilipidemic drugs in soils. Journal of Soils and Sediments. 11:13631372. doi:10.1007/s11368-011-0421-9

Lorah, M. M., I. M., Cozzarelli, and J.K. Böhlke, (2009), Biogeochemistry at a wetland sediment-alluvial aquifer interface in a landfill leachate plume. Journal of Contaminant Hydrology 105, no. 3-4: 99-117. https://doi.org/10.1016/j.jconhyd.2008.11.008

Madureira, T. V., Rocha, M. J., Cruzeiro, C., Rodrigues, I., Monteiro, R. A., and Rocha, E. (2012). The toxicity potential of pharmaceuticals found in the Douro River estuary (Portugal): evaluation of impacts on fish liver, by histopathology, stereology, vitellogenin and CYP1A immunohistochemistry, after sub-acute exposures of the zebrafish model. Environmental toxicology and pharmacology, 34(1), 34-45. https://doi.org/10.1016/j.etap.2012.02.007 
Manamsa, K., Lapworth, D. J., \& Stuart, M. E. (2016). Temporal variability of micro-organic contaminants in lowland chalk catchments: New insights into contaminant sources and hydrological processes. Science of the Total Environment, 568, 566-577. https://doi.org/10.1016/j.scitotenv.2016.01.146

Maurya, P. K., N. Balbarini, I. Møller, V. Rønde, A. V. Christiansen, P. L. Bjerg, E. Auken, and G. Fiandaca (2018), Subsurface imaging of water electrical conductivity, hydraulic permeability and lithology at contaminated sites by induced polarization, Geophysical Journal International, 213(2), 770-785. DOI.org/10.1093/gji/ggy018

Peschka, M., Eubeler, J. P. and Knepper, T. P. (2006). Occurence and fate of barbiturates in the aquatic environment. Environmental Science \& Technology, 40:23, pp. 7200-7206. doi:10.1021/es052567r

Ramette, A. (2007) Multivariate analyses in microbial ecology. FEMS Microbiology Ecology 62(2), 142-160. https://doi.org/10.1111/j.1574-6941.2007.00375.x

Rasmussen, J. J., McKnight U. S., Sonne A. Th., Wiberg-Larsen P., and Bjerg P. L. (2016), Legacy of a chemical factory site: contaminated groundwater impacts stream macroinvertebrates, Arch. Environ. Contam. Toxicol. (2016) 70: 219. https://doi.org/10.1007/s00244-015-0211-2

Roy, J. W. and G. Bickerton (2011), Toxic groundwater contaminants: An overlooked contributor to urban stream syndrome?, Environmental Science \& Technology, Vol. 46, Pages 729-736, doi:10.1021/es2034137.

Rügge, K., Bjerg, P. L., Pedersen, J. K., Mosbæk, H., \& Christensen, T. H. (1999). An anaerobic field injection experiment in a landfill leachate plume, Grindsted, Denmark: 1. 
Experimental setup, tracer movement, and fate of aromatic and chlorinated compounds. Water Resources Research, 35(4), 1231-1246.

Rønde, V., U. S. McKnight, A. Th. Sonne, N. Balbarini, J. F. Devlin, and P. L. Bjerg, (2017), Contaminant mass discharge to streams: comparing direct groundwater velocity measurements and multi-level groundwater sampling with an in-stream approach. Journal of Contaminant Hydrology, 206, 43-54. https://doi.org/10.1016/j.jconhyd.2017.09.010

Schaider, L. A., Rudel, R. A., Ackerman, J. M., Dunagan, S. C., and Brody, J. G. (2013). Pharmaceuticals, perfluorosurfactants, and other organic wastewater compounds in public drinking water wells in a shallow sand and gravel aquifer. Science of the Total Environment, 468-469, 384-393. doi:10.1016/j.scitotenv.2013.08.067

Sonne, A.T., McKnight, U.S., Rønde, V., and Bjerg, P.L., (2017), Assessing the chemical contamination dynamics in a mixed land use stream system, Water Research, 125, 141151. doi:10.1016/j.watres.2017.08.031.

Stuart, M.E., Lapworth, D.J., Thomas, J., and L. Edwards (2014). Fingerprinting groundwater pollution in catchments with contrasting contaminant sources using microorganic compounds. Sci. Total Environ. 468, 564e577.

Thiele-Bruhn S. and I.-C. Beck (2005), Effects of sulfonamide and tetracycline antibiotics on soil microbial activity and microbial biomass. Chemosphere, 59(4), 457-465. https://doi.org/10.1016/j.chemosphere.2005.01.023

US EPA, 2012. Estimation Programs Interface Suite ${ }^{\mathrm{TM}}$ for Microsoft巴 ${ }^{\circledR}$ Windows V. United States Environmental Protection Agency, Washington, DC, USA. The BIOWIN4 model 
can be downloaded free of charge from: https:// www.epa.gov/tsca-screeningtools/download-epi-suitetm- estimation-program-interface-v411

Vogel, T. M., Criddle, C. S., \& McCarty, P. L. (1987). Transformations of halogenated aliphatic-compounds. Environmental Science and Technology, 21(8), 722-736.

Walsh, C. J., Roy, A. H., Feminella, J. W., Cottingham, P. D., Groffman, P. M., and Morgan, R. P. (2005). The urban stream syndrome: current knowledge and the search for a cure. Journal of the North American Benthological Society, 24(3), 706-723. https://doi.org/10.1899/04-028.1

Westbrook, S.J., Rayner, J.L., Davis, G.B., Clement, T.P., Bjerg, P.L., and Fisher, S.J., (2005), Interaction between shallow groundwater, saline surface water and contaminant discharge at a seasonally and tidally forced estuarine boundary. Journal of Hydrology, 302, 255-269. doi:10.1016/j.jhydrol.2004.07.007

Figure 1: In a) the location of Grindsted town is indicated on a map of Denmark. In b) the urban area of Grindsted town (gray), the location of the Grindsted factory site (brown) north of the stream, the groundwater flow model domain (black lines), and the stream section where groundwater with high concentrations of chlorinated ethenes is discharging (solid red box) is shown. The contaminant plume originating from the factory site is indicated by the red dashed lines. The groundwater equipotential lines [m asl] and labels are marked with darker blue lines and numbers, respectively. The hydropotential map was developed by Balbarini et al. (2017) based on hydraulic head measurements from March $25^{\text {th }}-27^{\text {th }}$ 2012. Wells used to develop the groundwater flow model and to collect contaminant concentration samples are indicated by black dots. In c) the numerical model 
domain and associated grid are shown. Well numbers refer to the Danish national system (GEUS, 2018).

Figure 2: Cross-sections of the $3 \mathrm{D}$ geological model and hydraulic heads for the Grindsted factory site. a) The locations of the cross-sections (red dashed lines), the wells used for comparison with the simulated groundwater heads (black dots), the wells used for describing the boundary conditions (red dots) and the legend for the geological model are shown. b) Cross-section parallel to the stream; c) Cross-section along the main flow path from the factory site to the stream. The measured (blue dots) and simulated (blue lines) changes in hydraulic head over depth are shown at five wells with a total of eighteen screens in the two cross-sections. The hydraulic head was measured on 2007-2016 (1447) and 25-10-2016 (1448, 1495, 2507, 2508).

Figure 3: Simulated groundwater flow paths by particle tracking (red lines) and groundwater head (blue lines). The simulated equipotential lines have a $0.1 \mathrm{~m}$ head difference. The close-ups show the observed groundwater head and the estimated groundwater flow direction. Shaded areas around the arrows represent the standard deviation of the estimated flow direction (Devlin and Schillig, 2017).

Groundwater head and stream level were measured over the period of September $28^{\text {th }}$-October $25^{\text {th }}$ 2016.

Figure 4: Delineation of three contaminant plumes, one in the unconfined aquifer (red dashed line) and two in the semi-confined aquifer. In the semi-confined aquifer (b), one plume originates from the northern part of the factory site (encased within the black dashed lines) and one from the southern part of the factory site (blue dashed lines) discharging to Grindsted stream. The factory site is shown in brown. The plume delineation is based on the groundwater flow paths (red lines) and on 
the hydraulic equipotential lines (blue lines). Sampling locations are indicated by dots, color-coded according to the significant groupings determined by the statistical analysis (Figure S4).

Figure 5: Distributions over depth in 1988-1990 for selected compounds: ethyl urethane (EU, green), sulfanilamide (Sulf, gray), and benzene (Benz, orange) at three boreholes. Borehole locations are shown in Figure 1. The black dashed lines indicate the boundary between the shallow unconfined aquifer and the deep semi-confined aquifer. Compare to Figure 6 for current data. The peak concentration of sulfanilamide exceeding the y-axis at well 1447 is $2290 \mu \mathrm{g} / \mathrm{L}$.

Figure 6: Current distributions over depth for selected pharmaceutical compounds (chlorinated ethenes (CE, blue), ethyl urethane (EU, green), sulfanilamide (Sulf, gray), and benzene (Benz, orange)) in six boreholes. The borehole locations are shown in Figure 1. The concentration of chlorinated ethenes is expressed in PCE equivalents. The black dashed lines indicate the extent of the clay/lignite layer between the shallow unconfined aquifer and the deep semi-confined aquifer. This layer is not very pronounced in wells 2567 and 2568.

Figure 7: Comparison of the concentrations of five pharmaceuticals in groundwater measured in, spectively, 1988-1990 and 2012-2016. a) Down-gradient of the factory site, and b) near the stream; dotted line shows 1:1 ratio. Note that the scale is logarithmic and the y-axis title in $b$ ) is the same as a). See Table S1 for data on wells and sampling dates. 


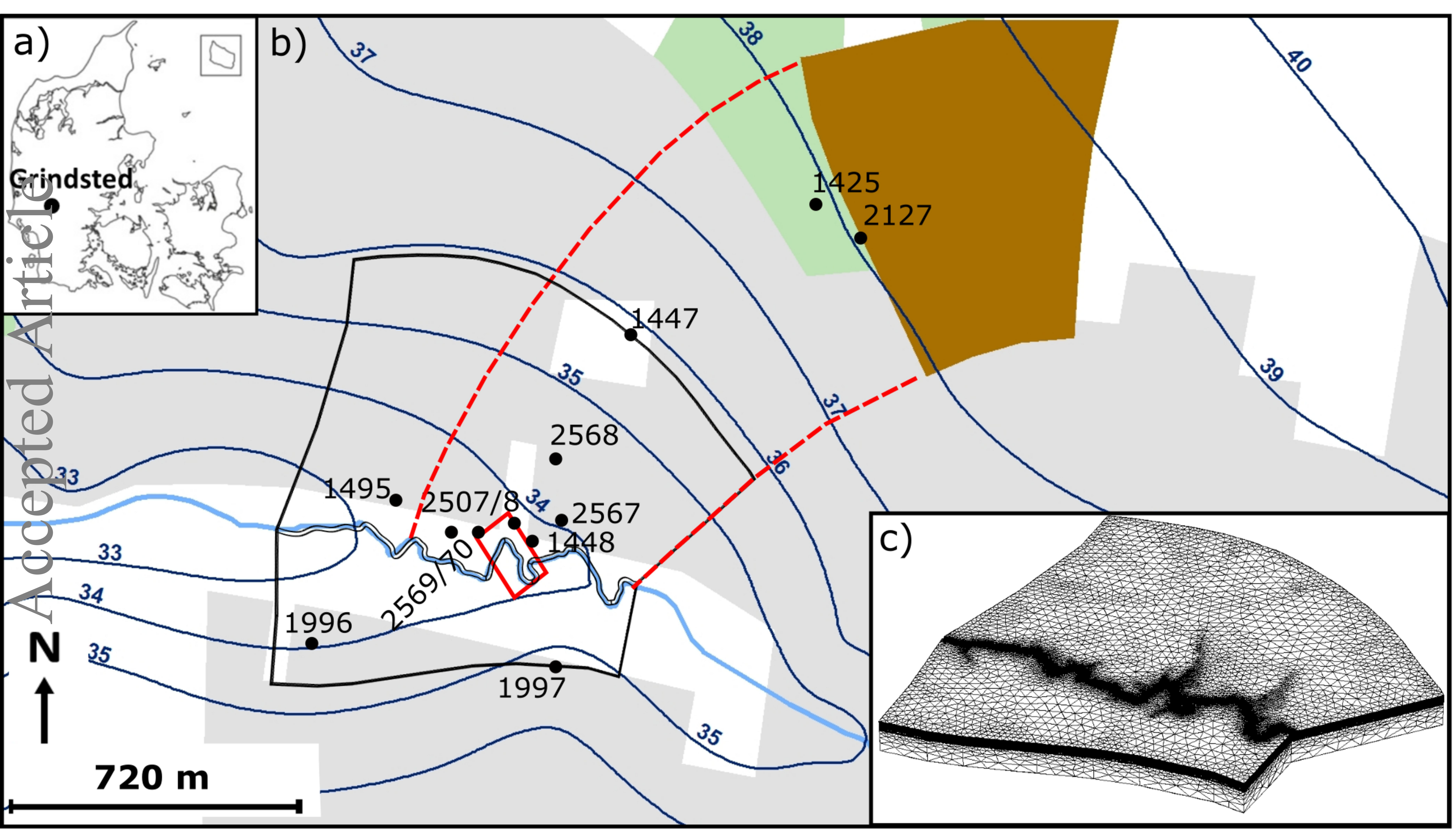



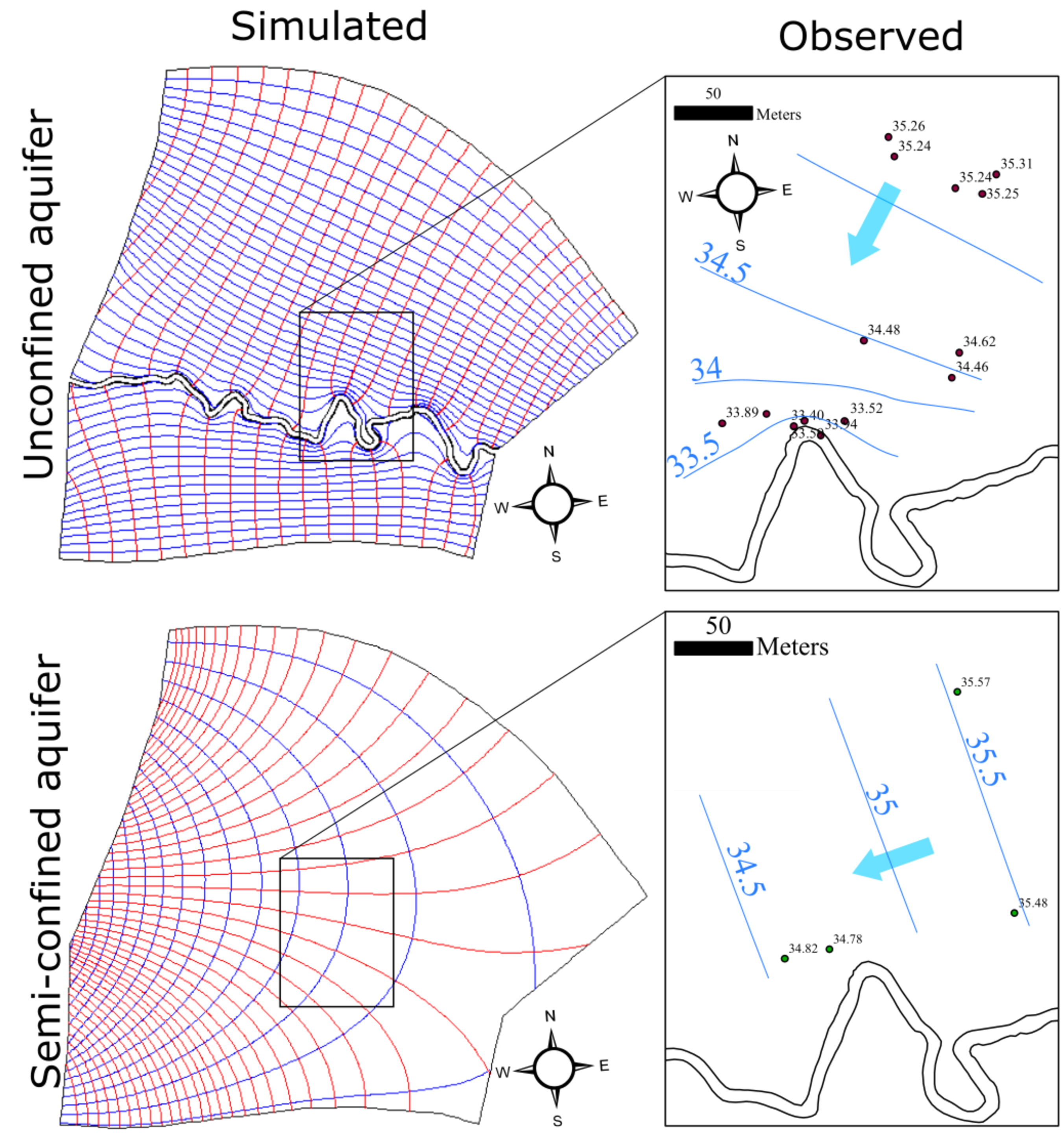


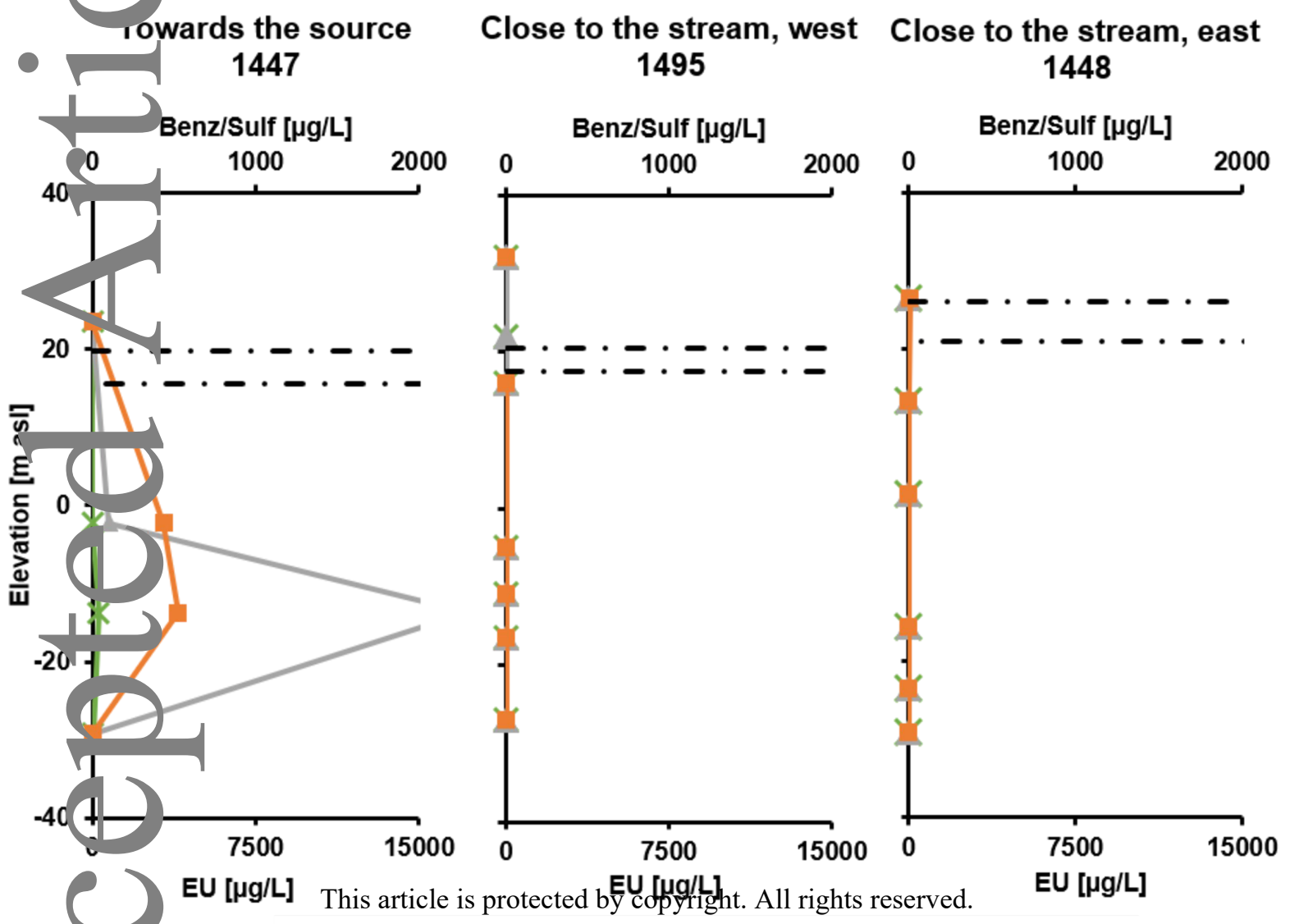


